\title{
S. fin
}

\section{Studies in Second Language Learning and Teaching}

Department of English Studies, Faculty of Pedagogy and Fine Arts, Adam M ickiewicz University, Kalisz

\section{Computer-mediated communication as an autonomy-enhancement tool for advanced learners of English}

\author{
Aleksandra Wach \\ Adam M ickiewicz University, Poznań, Poland \\ waleks@wa.amu.edu.pl
}

\begin{abstract}
This article examines the relevance of modern technology for the development of learner autonomy in the process of learning English as a foreign language. Computer-assisted language learning and computer-mediated communication (CMC) appear to be particularly conducive to fostering autonomous learning, as they naturally incorporate many elements of autonomy that give learners control over and responsibility for their own learning, such as choosing the materials used, managing their contact with various genres and types of interaction, often in authentic contexts, and evaluating their own progress, measured through their success in understanding and conveying meanings. However, providing access to language resources does not automatically lead to the development of autonomy, as much depends on other factors, such as the learners' level or previous experience in learner training. The present study investigated whether advanced learners of English made use of out-of-class CMC engagement for the purpose of learning English autonomously. The results indicate that most of the participants were eager to use CM Copportunities to deliberately practice their English, although, quite naturally, leisure and social reasons for using CM C predominated. The expressed willingness to deliberately focus on practicing English during beyond-theclassroom meaning-oriented online interactions confirms the great potential of CMC as an autonomy-enhancement tool.
\end{abstract}

Keywords: Computer-mediated communication (CMC), computer-assisted language learning (CAШ), learner autonomy, learning beyond the classroom 
In the last three decades, the development of learner autonomy has continued to be a major aim of language learning and teaching influenced by the learner-centered paradigm in education (Little, 2000; Reinders, 2011; Williams \& Burden, 1997). Although numerous definitions of the concept of learner autonomy have been offered, most of them focus on the control and responsibility that learners have in managing and evaluating their own learning. Increasingly, the social dimension of autonomy has been highlighted in recent literature on the subject, which stresses that autonomous learning needs to incorporate elements of interaction, with the teacher, with other learners, or other users of $L 2$, to prepare learners to function in communicative environments. One way of promoting autonomous behavior in foreign language learners is through the application of different forms of computer-assisted language learning (CALL), and, in particular, computer-mediated communication (CMC) in the process of language learning (Godwin-Jones, 2011; Kaur, Singh, \& Embi, 2006; Lee, 2011). Involvement in CMC provides learners with many core features of autonomous learning, such as management and evaluation of their own learning progress, making decisions on when and how they will engage in $\mathrm{CMC}$, managing interaction in the $\mathrm{L} 2$, independence as language learners, and interdependence among CMC participants (Benson, 2001, 2006, 2011; Blin, 2004; Jarvis, 2012; Reinders \& White, 2011). The question remains, however, whether, by providing ample access to autonomous learning opportunities, CMC engagement actually fosters learner autonomy development (Benson, 2011a; Blin, 2004). Previous research into the relationship between CALL environments and learner autonomy points to the potential of computer-enhanced learning resources as a contributor to $L 2$ learners' autonomous learning. Nevertheless, limitations and problems have often been voiced, such as the interplay of individual factors and autonomy capacities, or learners' inability to use the available resources effectively without a teacher's assistance. $M$ ore research is definitely needed to verify the benefits of participating in technology-based learning for the development of learner autonomy.

Therefore, the study described in this article aimed to investigate whether beyond-the-classroom participation in CMC in English was perceived by the study participants (201 advanced learners of English) as an opportunity to practice English on their own and to foster their management of their own learning processes; in other words, the study aimed to investigate the link between outof-class involvement in different forms of $\mathrm{CMC}$ and autonomous language learning. The results indicate that $\mathrm{CM} C$ engagement was pursued primarily for leisure and social reasons, but at the same time the participants attended to the language forms and deliberately practiced their vocabulary, grammar and communicative skills in the course of their online interaction. This reveals the huge potential of CMC for fostering autonomous language learning. The teaching impli- 
cations, however, include the need to offer guidance and help learners monitor their own autonomous learning experience to exploit its full potential.

\section{Autonomy in Today's L2 Learning}

The concept of autonomy in language learning and teaching has stemmed from the general paradigm of learner-centered instruction, which was influenced by humanistic psychology (Little, 2000; Ushioda, 2011b; Williams \& Burden, 1997). As noted by Benson (2001, p. 8), the concept was first introduced in 1971, and was later explored and popularized by Henri Holec's (1981) seminal work Autonomy and Foreign Language Learning. Autonomy, defined broadly as "the capacity to take charge of one's own learning" (Holec, 1981, p. 3), involves several components and capacities on the part of learners. One of them is the skill of self-directed learning, in which "the objectives, progress and evaluation of learning are determined by learners themselves" (Benson, 2001, p. 8). Benson $(2006, p$. 22) further explains that taking responsibility for one's learning involves planning abilities, the ability and readiness to select appropriate learning materials, constant monitoring of one's learning progress, and the ability to evaluate the outcomes of learning. Little (2000, pp. 69-70) lists critical reflection, decision making and independent action as basic components of autonomous learning, through which learners become managers of their own learning according to their needs and available learning options. Moreover, autonomous learners are able to transfer their learning to new learning environments and try to use their knowledge in various contexts of autonomous target language use. This often entails affective engagement and positive motivation. Gao and Zhang (2011) add agency, metacognition and learning strategies as prerequisites for autonomous learning, as these enable learners to understand the nature of learning processes and help support their learning efforts. Therefore, training learners in the use of cognitive and metacognitive strategies is an important step in leading them toward autonomy (Darasawang \& Reinders, 2010).

Moreover, recently researchers have highlighted the social dimension of autonomous learning. Little $(2009$, p. 223) summarizes the social dimension of autonomy by saying: "Autonomous learners always do things for themselves, but they may or may not do things on their own." As stated by Benson (2011a, p. 16), "autonomy is a social construct that implies interdependence rather than independence." Lee $(2011$, p. 88) adds that "through social interactions, learners develop a capacity to analyze, reflect upon and synthesize information to create new perspectives." Taking into account the social context of learning raises the question of learner identity, which is another notion embedded in the contemporary 
understanding of the concept of autonomy; autonomous learning embraces expressing one's identity through the target language (Ushioda, 2011a).

\section{The Link Between Computer-M ediated Communication and L2 Learners' Autonomy}

According to Benson (2006, 2011a, 2011b), recently there has been increased interest in autonomy promoted by out-of-class learning contexts, technology-mediated communicative situations being part of them. Drawing upon the use of technology for promoting autonomy stems from the constructionist, or the social-constructivist view on language learning (Hafner \& Miller, 2011; Luzón \& Ruiz-Madrid, 2008; Sadik, 2008; Villanueva, Ruiz-Madrid, \& Luzón, 2010), as it incorporates learners' creativity, problem solving abilities, critical thinking and the social context of learning.

Benson (2001) emphasizes that technology has the potential to foster autonomous behavior in learners because it facilitates self-access in learning, and gives learners many valuable opportunities to self-direct their learning and take control over it. Using technology-based materials gives students more responsibility for learning and can enhance their intrinsic motivation (Darasawang \& Reinders, 2010). Reinders and White (2011) highlight increased interaction opportunities and fostering situated learning in beyondthe-classroom contexts as benefits derived from technology-based learning, while Collentine (2011, p. 51) claims that CALL "can help learners modify input, gauge learning, monitor progress, reflect on and prioritize their learning," and, in this way, promote autonomous learning and positively affect learners' linguistic awareness. Markiewicz (2008) stresses the individualized character of instruction, easily adaptable to individual learners' needs and capacities, as a feature of distance learning which makes it particularly suitable for fostering learners' autonomy. According to Blin (2004), CALL naturally allows learners to control some aspects of learning, while CMC additionally gives them some control over interaction in L2. Alm (2006) states that Web 2.0 tools constitute new learning environments which offer valuable opportunities for learners at various levels and with specific needs, while Reinders and White (2011, p. 2) perceive the ability to navigate different learning environments as a vital component of autonomous learning as the term is currently understood.

Moreover, learners' engagement in CMC has revealed the great potential of the social domain of technology-based learning, which can contribute to autonomy development in the sense of interdependence among L2 users rather than autonomy as learner independence (Eneau \& Develotte, 2012; Reinders \& White, 2011). According to Villanueva et al. (2010), the potential of 
technology-mediated language learning for autonomy development lies in that it involves a number of authentic resources, genres and forms of interaction in both pedagogical and nonpedagogical contexts.

Kaur et al. (2006), Kaur and Sidhu (2010), and Abraham and Williams (2011), focusing on the application of CM C by students at institutions of higher education, stress the lifelong learning dimension of autonomy development that is particularly relevant in the case of adult language learners. Hyland (2004) makes a similar point, stressing the relevance of autonomy enhancement for lifelong learning among university students through the pursuit of offline and online out-of-class learning opportunities. $\mathrm{Ng}$, Confessore, Yusoff, Aziz, and Lajiz (2011), apart from discussing the link between autonomy and adult learners' capacity for lifelong learning, highlight the correlation between levels of autonomy and academic success.

However, as noted by Reinders and White $(2011$, p. 1), the relationship between technology-based teaching and autonomy development may not be very clear, as "unrestricted access to information, without proper guidance and feedback, can in fact inhibit learners from taking more responsibility." Benson (2001, 2006, 2011a) notes that although new technology involves autonomous learning, it is still not clear whether and to what extent it fosters such learning. The effectiveness of technology-based approaches depends largely on the way in which technology is applied, the level of interaction that is stimulated, and the degree of control that learners themselves have in manipulating the content. Therefore, Luzón and Ruiz-Madrid (2008, p. 28) point to the role of instructors in helping learners become autonomous through technology-based resources: "In order to help students harness the potential of ICT for the development of an autonomising competence, it is necessary to carefully design learning environments or learning tasks that promote the active use of metacognitive strategies, that is, that prompt students to plan, monitor and evaluate their own learning." Similarly, Reinders (2011) points out the need for learner training and ongoing teacher support as a supplement to providing access to autonomy-building resources. Blin (2004) and Esch and Zähner (2000) maintain that some level of autonomy is probably required in order to allow learners to take full advantage of the use of computer applications in learning. Therefore, more research is needed to verify the potential of technology on learners' autonomy development.

Some studies, however, have attempted to investigate the relationship between using different forms of CALL and CMC and learner autonomy. These studies indicate that while engaging in computer-based learning activities, apart from developing language skills, learners have a chance to discover ways of approaching linguistic and interactive tasks to a large extent independently 
of the teacher and hence the metacognitive and affective sides of their learning are involved. For example, Ushioda (2000) focused on the affective dimension of technology-based learning, concluding that tandem email exchanges by L2 German learners increased their intrinsic motivation and may have fostered learner autonomy. Arikan and Bakla (2011) conducted a study on a group of Turkish university students and found that experience with blogging contributed to their developing autonomy. In Shucart, Mishina, Takahashi, and Enokizono's (2008) study, a blended learning tool fostered learner autonomy in classroom-based and out-of-class learning among their study participants through promoting collaboration among learners and increasing their intrinsic motivation and positive attitudes toward learning situations. Jarvis (2012) observed in his study that the application of technology impacted considerably the study participants' autonomous learning in self-study centers.

Some studies, however, while indicating the promises of CALL environments for fostering autonomy, also point to some of the limitations or problems associated with them. Their findings confirm Reinder and White's (2011) concern that computer-based learner involvement does not necessarily lead to increased responsibility for managing learning. For example, Kaur and Sidhu (2010) found that asynchronous online interactions through email had the potential to stimulate autonomy development in Malaysian university students, but some training in the application of optimal learning tools was needed to make the experience more effective. Eneau and Develotte (2012), who explored the effects of a distance learning project on adult L2 French learners' autonomy, concluded that numerous factors are interrelated in this form of learning, influencing the degree of autonomy development. These factors included the strategies used by learners to overcome distance learning problems and the social and emotional dimension of learner collaboration. Hafner and Miller (2011) recorded enhanced autonomous learning capacities in Hong Kong university students of Science as a result of their taking part in a digital video project. They noted, however, that some features of informal learning incorporated in the project helped achieve this aim.

Lee's (2011) study explored the effects of self-reflection and social processes engendered by a blogging-based project on the development of autonomy in U.S. students studying abroad. She found out that autonomy development was dependent on the task type and proper application of metacognitive and cognitive skills. Luke (2006), who investigated the effects of a technology-based, learner-centered course for $L 2$ Spanish learners on their autonomy development and attitudes toward the innovations in teaching, recorded mixed opinions on the part of the participants, from very positive to rather negative. He concluded that novel solutions need careful implementation and constant support from educators, as 
the assumption of new responsibilities by learners is not easy. In a study conducted on L2 French learners by Raby (2007), motivation and autonomy were fostered through a technology-based task. The researcher concluded that being given control over the way the task was completed, incorporating the learners' own preferences, was appreciated by the participants; however, the technological dimension turned out to be less important than the pedagogical dimension of the activity. Wolski (2008) explored Polish university students' use of Internet resources as part of their autonomous independent self-study; concluding that although the participants reported frequently resorting to computer-based resources, he felt that a tutor's help was needed to demonstrate how to find the most valuable materials and how to make effective use of them.

To conclude, research in the area of tracing the links between the use of new technology and fostering learner autonomy has indicated a great potential of various CALL applications for pursuing autonomous behaviors on the part of L2 learners. On the other hand, it has also revealed that despite this potential, engaging in technology-based activities may not contribute much to the development of autonomy, as a variety of learner and contextual factors appear to influence considerably the levels of autonomy development in learners. Furthermore, the reasons why learners get involved in CALL or online interactions seem to be an important factor influencing the degree to which such activities foster autonomous learning or are signs of autonomous behavior. While all of the studies presented above focused on the use of technology for promoting autonomy in formal educational L2 settings, usually through educational projects set up by teachers, the present study investigates EFL learners' engagement in $\mathrm{CMC}$ in naturalistic settings, in their own time, beyond the classroom, and for any reason (including both leisure and academic activity).

\section{The Study}

\section{Aims of the Study}

The main aim of the study was to investigate whether out-of-class involvement in $\mathrm{CMC}$ fostered autonomous learning in the study participants according to their own estimations. Within the scope of this study, autonomy is understood as taking responsibility for managing and regulating one's own learning, which involves using various opportunities to learn and practice $L 2$, consciously attending to the form and use of $L 2$, and the ability to reflect on learning processes, which stimulates the "generally proactive approach" (Little 2009) toward learning.

In order to achieve this primary aim, several additional aims were formulated. One of them was to find out the frequency of the participants' in- 
volvement in different forms of $\mathrm{CMC}$ in their own time, as a beyond-theclassroom activity, and the languages used during CM C. Moreover, the study investigated whether the participants evaluated themselves as autonomous learners of English, and, finally, whether there were differences between regular and part-time students with regard to their self-evaluated learner autonomy and their perceptions of CMC as an autonomy-enhancement tool.

\section{Participants}

In total, 201 participants took part in the study, all of whom were adult advanced learners of English as a foreign language. They were majoring in English in years 1-3 of the BA program at Adam Mickiewicz University in Poznań. A majority of the participants (195) were Polish, while 6 were of other nationalities. For the purposes of the study, the participants were divided into two groups: Group A ( $n=149)$ included regular students, and Group B $(n=52)$ included part-time students. The median age of the Group A students was 21 (min. 19, max. 28), and the median age in Group B was 23.5 (min. 20, max. 41).

The differences between both groups of the study participants were considered important within the scope of the study for a few reasons. While the regular students (Group A) had classes during the week and studying was their main occupation, part-time students (Group B) attended classes on Saturday and Sunday every second week and worked during the remaining days of the week. As a result, it may be assumed that, while for the majority of Group A students academic activity was their main occupation, the majority of Group B students were occupied with their full-time jobs, family duties, and academic activity. As a result, Group B students might have had less time and energy both for academic activity and for engaging in $\mathrm{CMC}$; moreover, considerably less frequent contact with English during classes and other university-based activities might have necessitated more autonomous learning behaviors in this group.

Moreover, while a course in Information Technology was offered to regular students in the first year of their BA studies, there was no such a course in the parttime students' syllabus. The university has an e-learning platform, but whether and to what extent it was used for courses depended on particular teachers.

\section{Data Collection}

One data collection tool used in the study was Questionnaire 1 consisting of 6 closed-ended questions which elicited answers connected with the participants' Internet use habits, and 16 closed-ended Likert-type items focusing specifically on autonomy-related issues in which the participants marked 
the best-matching answer on a 5-point scale, where 1 meant I strongly disagree, and 5 meant I strongly agree. Cronbach's alpha for the Likert-type items was .802, suggesting a high degree of internal reliability. T-test values were calculated for the items and statistical significance was set at the level of .10.

Another data collection tool, Questionnaire 2, consisted of two open-ended cues: "Do you consider yourself an autonomous learner of English? Please justify your answer briefly," and: "If/When you take part in computer-mediated communication (through e-mails, instant messaging, blogging, etc.) in English, do you do it just for pleasure or social reasons, or do you ever intentionally plan to improve your English through CMC?" The cues were sent to the study participants via email two weeks after the administration of the closed-ended questionnaire; however, the response rate was very poor, as only 12 out of the 201 participants sent back their answers. The forms of both research tools are enclosed in the Appendix.

\section{Results}

Questionnaire 1. The initial questions concerned the participants' Internet use habits. According to the responses, the average time spent on CMC was 2.5 hours daily on weekdays and 3.2 hours daily at weekends.

Figures 1, 2 and 3 present the percentages of responses concerning using particular forms of $\mathrm{CMC}$ and the languages in which they were used: Figure 1 illustrates the participants' engagement in these CM C forms in L1, Figure 2 in English, and Figure 3 - in other languages.

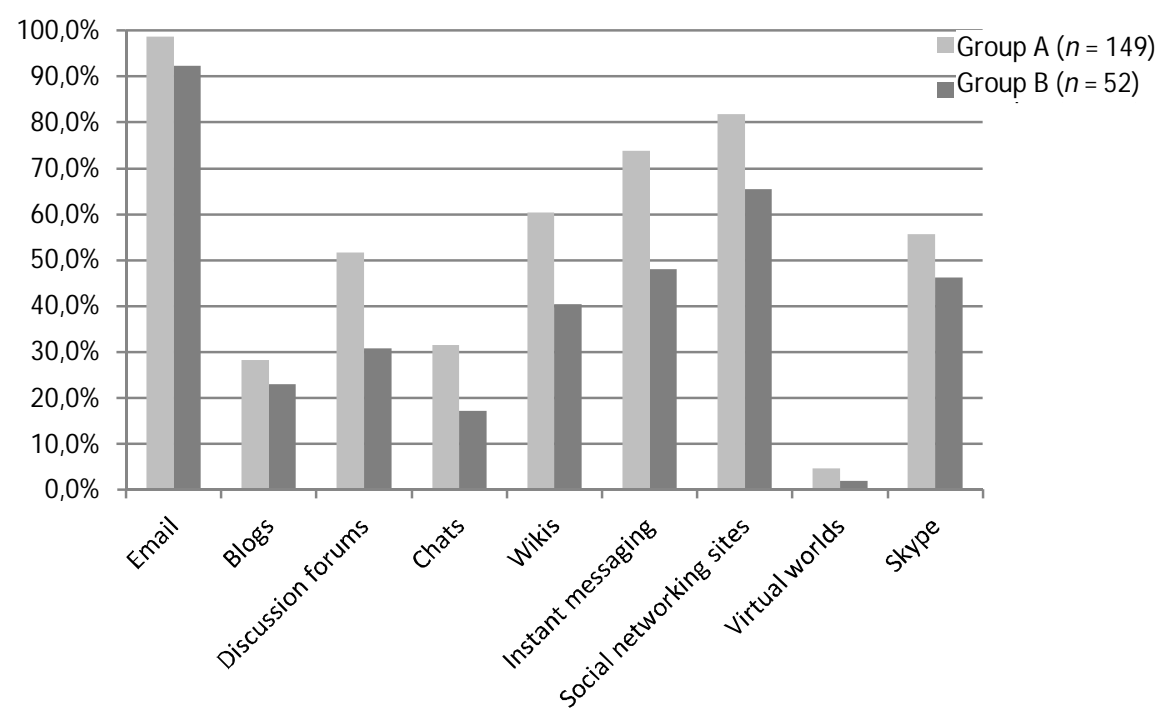

Figure 1 The participants' account of using different $\mathrm{CM}$ C forms in the native language 


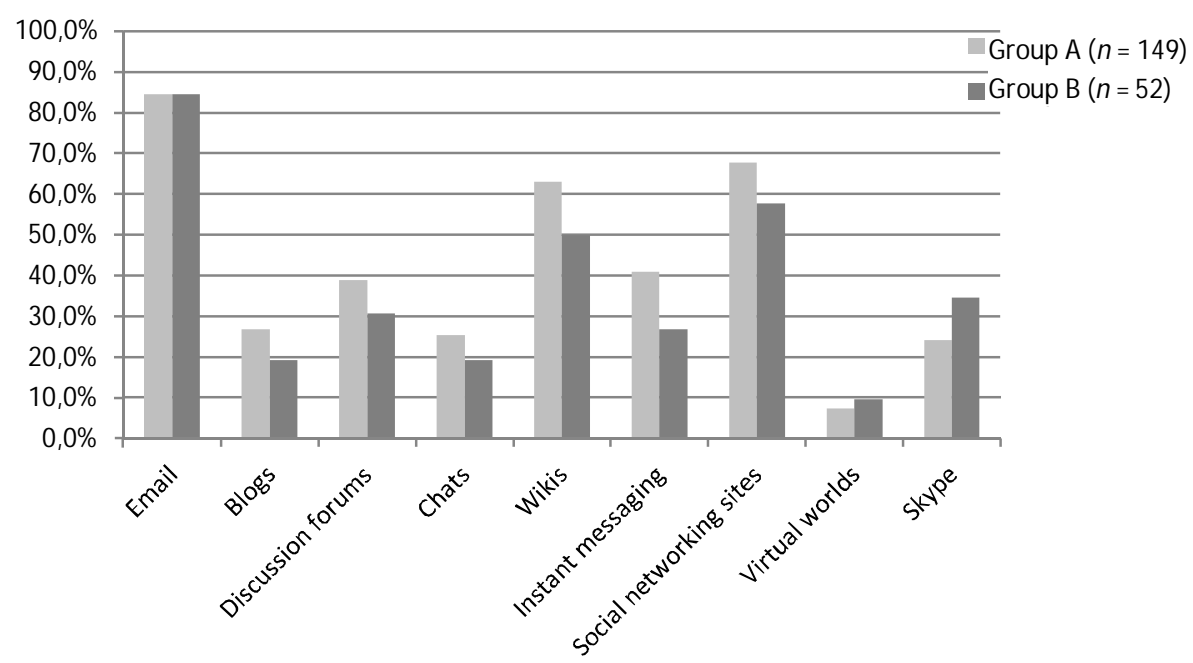

Figure 2 The participants' account of using different CM C forms in English

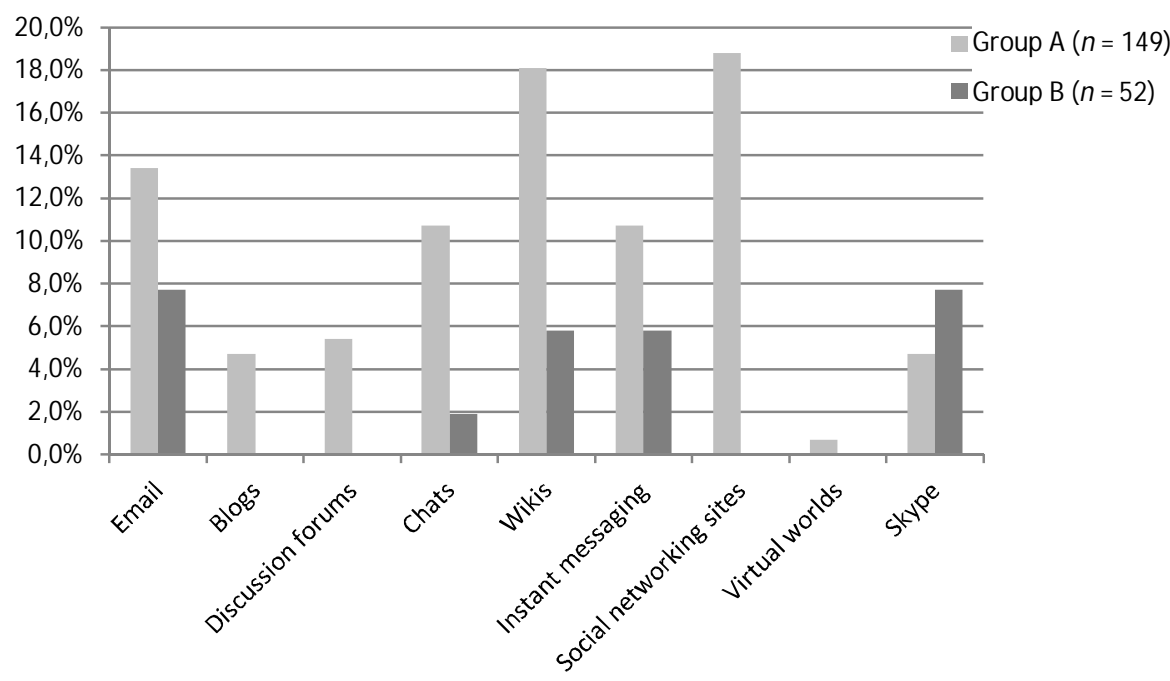

Figure 3 The participants' account of using different CM C forms in other languages

As can be seen in Figures 1, 2 and 3, all forms of CM C were used by the participants, email being the most popular one, at least in L1 and in English, participation in virtual worlds being the least popular activity. The high percentages of participation in different forms of CMC in English (Figure 2) are worth mentioning, as this points to the respondents' having additional, out-of-class contact with English. More than $80 \%$ of the respondents in each group wrote emails in English, and participation in other CMC forms (blogging, discussion forums, and social networking sites) was almost as popular in English as it was in 
Polish, and sometimes it was even more popular in English than in Polish (in the case of Group B's chatting, and wikis for both groups). Generally, as the data in the figures indicate, more regular (Group A) students participated in different forms of CMC, in L1, in English and in other languages (such as German, Spanish, Russian, and even Japanese), than did part-time (Group B) students.

Further on, Figure 4 illustrates the frequency of participation in $\mathrm{CM} C$ in general, and Figure 5 presents data concerning the frequency of the participants' use of English in CMC. As can be seen in Figure 4, most of the respondents in both groups took part in CM C every day, while very few of them participated in CM C once a week or less frequently.

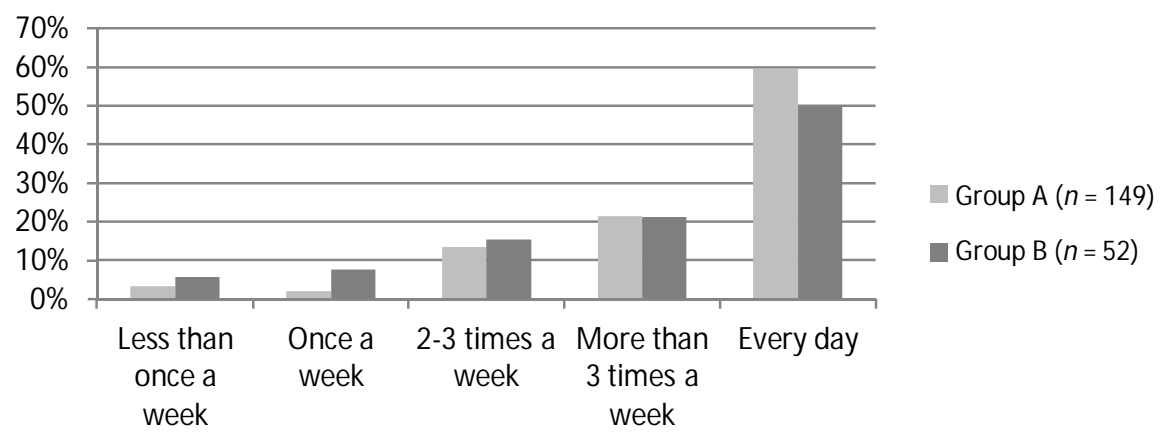

Figure 4 Frequency of engagement in CM C

According to the data in Figure 5, sometimes was the most frequently marked answer concerning the frequency of using English while engaging in $\mathrm{CMC}$, although the often and very often options were also frequently indicated. The results appear to be similar in the case of both groups.

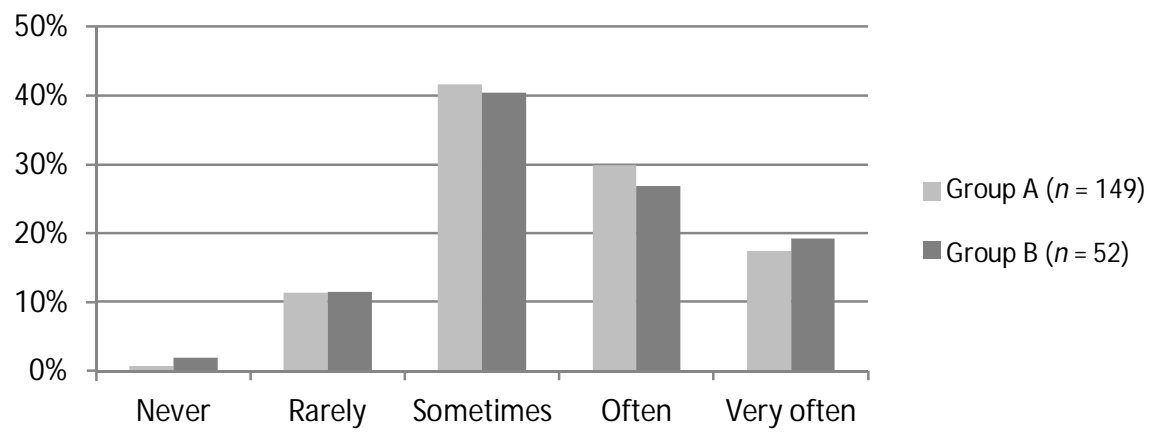

Figure 5 Frequency of engagement in $\mathrm{CM}$ C in English

Tables 1, 2, 3 and 4 present the participants' responses to the Likerttype items connected with their autonomous learning behavior. The items 
have been grouped under four headings: the respondents' planning abilities, their self-evaluation abilities, their learning strategy use and their perception of $\mathrm{CMC}$ as an autonomy development tool.

Table 1 presents the participants' answers to four items connected with their planning abilities in the process of $L 2$ learning. As can be seen, more parttime (Group B) than regular (Group A) students admitted having well-defined objectives in learning English. However, although for the remaining items the differences between the groups appeared not to be statistically significant, a similar pattern was revealed: part-time students' responses pointed to higher levels of planning and organizing their learning processes.

Table 1 The participants' perceptions about their abilities to plan their learning

\begin{tabular}{|c|c|c|c|c|c|c|}
\hline & $\begin{array}{r}\text { (Strongly) } \\
\text { disagree }\end{array}$ & No opinion & $\begin{array}{r}\text { (Strongly) } \\
\text { agree }\end{array}$ & M & SD & $\begin{array}{r}\text { Sig. (two- } \\
\text { tailed) }\end{array}$ \\
\hline & \multicolumn{6}{|c|}{ I have well defined objectives in learning English. } \\
\hline Group A & $8.7 \%$ & $26.2 \%$ & $65.1 \%$ & 3.44 & .961 & \multirow{2}{*}{.036} \\
\hline Group B & $1.9 \%$ & $13.5 \%$ & $84.4 \%$ & 4.08 & .763 & \\
\hline & \multicolumn{6}{|c|}{ I learn English regularly, according to my own plan. } \\
\hline Group A & $18.1 \%$ & $13.5 \%$ & $68.4 \%$ & 3.68 & 1.048 & \multirow{2}{*}{.510} \\
\hline Group B & $17.3 \%$ & $5.8 \%$ & $77.0 \%$ & 3.79 & 1.016 & \\
\hline & \multicolumn{6}{|c|}{ I know how to look for appropriate materials for improving my English. } \\
\hline Group A & $9.4 \%$ & $10.7 \%$ & $79.9 \%$ & 3.95 & .853 & \multirow{2}{*}{.179} \\
\hline Group B & $9.6 \%$ & $5.8 \%$ & $84.7 \%$ & 4.13 & .908 & \\
\hline & \multicolumn{6}{|c|}{ I know what helps me learn most effectively. } \\
\hline Group A & $6.7 \%$ & $15.4 \%$ & $77.8 \%$ & 4.00 & .870 & \multirow{2}{*}{.681} \\
\hline Group B & $7.7 \%$ & $11.5 \%$ & $80.8 \%$ & 4.06 & .873 & \\
\hline
\end{tabular}

Table 2 presents the participants' opinions about their ability to evaluate themselves in the process of learning. Apparently, the respondents in both groups expressed a strong belief in their evaluation abilities, although this belief was shared by more part-time than regular students, and, moreover, significantly more part-time than regular students evaluated themselves as independent learners. Most of the respondents in both groups, however, admitted that they still needed regular feedback from their teachers.

It can be seen in Table 3 that the respondents admitted to using other materials of their own choice; similarly, a majority of the respondents in both groups stated that they took any opportunity to have contact with English. Again, the responses were more positive among part-time students. Looking for communication opportunities with native speakers of English was also marked as common practice by respondents in both groups. 
Table 2 The participants' perceptions about their abilities to evaluate their own progress

\begin{tabular}{|c|c|c|c|c|c|c|}
\hline & $\begin{array}{r}\text { (Strongly) } \\
\text { disagree }\end{array}$ & No opinion & $\begin{array}{r}\text { (Strongly) } \\
\text { agree }\end{array}$ & M & SD & $\begin{array}{l}\text { Sig. (two- } \\
\text { tailed) }\end{array}$ \\
\hline & \multicolumn{6}{|c|}{ I know how to evaluate my own progress in English. } \\
\hline Group A & $10.7 \%$ & $32.2 \%$ & $57.1 \%$ & 3.59 & 892 & \\
\hline \multirow[t]{2}{*}{ Group B } & $9.6 \%$ & $15.4 \%$ & $84.6 \%$ & 3.92 & .904 & $.0 \angle 2$ \\
\hline & \multicolumn{6}{|c|}{ I need regular feedback from teachers on how well I perform. } \\
\hline \multirow{3}{*}{$\begin{array}{l}\text { Group A } \\
\text { Group B }\end{array}$} & $27.5 \%$ & $18.1 \%$ & $54.3 \%$ & 3.29 & 1.153 & \\
\hline & $30.8 \%$ & $19.2 \%$ & $50.0 \%$ & 3.25 & 1.135 & .835 \\
\hline & \multicolumn{6}{|c|}{ I am an independent learner. } \\
\hline Group A & $20.8 \%$ & $23.5 \%$ & $55.7 \%$ & 3.47 & 1.112 & 007 \\
\hline Group B & $15.4 \%$ & $5.8 \%$ & $78.9 \%$ & 3.94 & .998 & 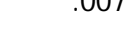 \\
\hline
\end{tabular}

Table 3 The participants' perceptions about the learning strategies they use to improve their English

\begin{tabular}{|c|c|c|c|c|c|c|}
\hline & $\begin{array}{r}\text { (Strongly) } \\
\text { disagree }\end{array}$ & No opinion & $\begin{array}{r}\text { (Strongly) } \\
\text { agree }\end{array}$ & M & SD & $\begin{array}{l}\text { Sig. (two- } \\
\text { tailed) }\end{array}$ \\
\hline & \multicolumn{6}{|c|}{$\begin{array}{l}\text { Apart from the materials given by my teachers, I use other materials of my } \\
\text { own choice. }\end{array}$} \\
\hline Group A & $8.0 \%$ & $14.1 \%$ & $77.8 \%$ & 3.94 & .887 & \multirow[b]{2}{*}{077} \\
\hline \multirow[t]{2}{*}{ Group B } & $7.7 \%$ & $5.8 \%$ & $86.6 \%$ & 4.19 & .864 & \\
\hline & \multicolumn{6}{|c|}{ I take any opportunity to have contact with English. } \\
\hline Group A & $8.7 \%$ & $17.4 \%$ & $73.9 \%$ & 3.93 & .938 & \multirow[b]{2}{*}{.081} \\
\hline \multirow[t]{2}{*}{ Group B } & $9.6 \%$ & $7.7 \%$ & $82.7 \%$ & 4.19 & .931 & \\
\hline & \multicolumn{6}{|c|}{ I look for opportunities to communicate in English with native speakers. } \\
\hline Group A & $14.8 \%$ & $20.8 \%$ & $64.4 \%$ & 3.68 & 1.007 & \multirow{2}{*}{.702} \\
\hline Group B & $23.1 \%$ & $11.5 \%$ & $65.4 \%$ & 3.75 & 1.203 & \\
\hline
\end{tabular}

As can be seen in Table 4, considerably more part-time than regular students declared participating in CMC in order to improve their English; however, interestingly, high percentages of the respondents were not sure whether their use of CMC was aimed at improving their English. A majority of the respondents (but more part-time students) admitted to deliberately focus on the linguistic forms that appear in CMC through, for example, looking up the vocabulary items they came across while communicating through the Internet, or paying attention to the forms used by other CM C users. In addition, a majority of the respondents in both groups stated that they deliberately practiced their reading skills through $\mathrm{CMC}$, while the answers with regard to practicing listening skills differed significantly between the groups (with more part-time students agreeing with the statement). Using CMC for communicating with tutors did not appear to be common practice for the respondents. 
Table 4 The participants' perceptions about their involvement in CMC with the aim of improving their English

\begin{tabular}{|c|c|c|c|c|c|c|}
\hline & $\begin{array}{r}\text { (Strongly) } \\
\text { disagree }\end{array}$ & No opinion & $\begin{array}{r}\text { (Strongly) } \\
\text { agree }\end{array}$ & M & SD & $\begin{array}{l}\text { Sig. (two- } \\
\text { tailed) }\end{array}$ \\
\hline & \multicolumn{6}{|c|}{ I deliberately take part in CMC in order to improve my English. } \\
\hline Group A & $26.1 \%$ & $30.9 \%$ & $42.9 \%$ & 3.21 & 1.075 & \multirow{2}{*}{.033} \\
\hline Group B & $17.3 \%$ & $23.1 \%$ & $59.6 \%$ & 3.58 & .957 & \\
\hline \multicolumn{7}{|c|}{ I look up new vocabulary items which I come across through CMC. } \\
\hline Group A & $11.1 \%$ & $12.1 \%$ & $75.9 \%$ & 3.85 & 1.042 & \multirow{2}{*}{.047} \\
\hline Group B & $5.8 \%$ & $11.5 \%$ & $82.7 \%$ & 4.17 & .857 & \\
\hline \multicolumn{7}{|c|}{ I pay attention to the language forms which other CM C users use. } \\
\hline Group A & $9.4 \%$ & $14.1 \%$ & $76.5 \%$ & 3.97 & .989 & \multirow{2}{*}{.400} \\
\hline \multirow[t]{2}{*}{ Group B } & $5.7 \%$ & $7.7 \%$ & $86.6 \%$ & 4.10 & .846 & \\
\hline & \multicolumn{6}{|c|}{ I deliberately practice my reading skills through CMC. } \\
\hline Group A & $16.7 \%$ & $28.2 \%$ & $55.1 \%$ & 3.47 & 1.063 & \multirow{2}{*}{.204} \\
\hline \multirow[t]{2}{*}{ Group B } & $19.2 \%$ & $21.2 \%$ & $59.6 \%$ & 3.69 & 1.147 & \\
\hline & \multicolumn{6}{|c|}{ I deliberately practice my listening skills through CM C. } \\
\hline Group A & $27.5 \%$ & $26.8 \%$ & $45.6 \%$ & 3.21 & 1.193 & \multirow{2}{*}{.030} \\
\hline \multirow[t]{2}{*}{ Group B } & $21.2 \%$ & $17.3 \%$ & $61.6 \%$ & 3.62 & 1.051 & \\
\hline & \multicolumn{6}{|c|}{ I communicate through CM C in English with my tutors. } \\
\hline Group A & $45.0 \%$ & $18.1 \%$ & $36.6 \%$ & 2.73 & 1.282 & \multirow{2}{*}{.575} \\
\hline Group B & $53.8 \%$ & $9.6 \%$ & $36.5 \%$ & 2.62 & 1.286 & \\
\hline
\end{tabular}

Questionnaire 2. The descriptive accounts provided by the participants in the follow-up open-ended questionnaire gave a more explanatory, in-depth perspective on the quantitative data described above. The responses provided to the question concerning the respondents' autonomy as foreign language learners mainly highlighted their involvement in self-study, which does not include having to do a task assigned by a teacher. The following quotes given by two participants illustrate this approach: "I consider myself an autonomous learner because I study even when nobody forces me to do so or even if I don't have any exam at the end;" "I feel that I could be considered as an autonomous learner as my learning of English is not limited to attending and preparing to the university classes. I regularly extend my knowledge on my own accord by self-study." Although undertaking self-study may characterize autonomous learners, being autonomous involves much more than that. Other characteristics of autonomous learners, such as the ability to take responsibility for one's learning and to manage the learning process, or the ability to reflect upon one's learning, were not mentioned by the study participants. On the contrary, some quotes indicated an incomplete understanding of the concept, for example, by differentiating among areas of language study where a student is or is not autonomous. This is illustrated by the following example: "I am not fully autonomous because it depends on the area of learning. I feel 
autonomous in learning vocabulary and phonetics, as I study on my own, but in the case of grammar I need some guidance from teachers." This example shows that the respondent associated autonomy in learning solely with independence of teachers rather than with an ability to refer to and effectively use various available resources in the process of learning.

Further comments shed more light on the respondents' understanding of the concept of autonomy. Apart from mentioning the effort put in self-study, one respondent wrote about asking for assistance as a learning strategy which he/she employed: "I try to understand the material and search on my own, but if I don't understand something or have problems, I ask others (e.g. teachers) for help." It is important to note that the comment about asking for help was meant to be an apology for not being independent enough, and hence, not autonomous enough. Still another respondent focused on the affective side of being an autonomous learner by writing: "I am an autonomous learner because I don't treat learning the language as a duty, I do it for my personal benefits, due to my willingness, remaining in accordance with my initial choice of my studies. Final exams are only an incentive for meticulous preparation and thorough study, but not an ultimate goal." Apparently, this quote points to high levels of intrinsic motivation, which may, in fact, contribute to learner autonomy. It also stresses the ability of setting his/ her own goals on the part of the student, a feature typically associated with autonomous behavior.

The clue concerning the respondents' applications of CMC for the purpose of learning English generated some responses which highlighted the purely leisure and social dimension of CM C engagement, as exemplified by the following quote: "Usually I participate in CMC just for pleasure and social reasons." However, most of the responses revealed a balanced approach, in which both social and linguistic aims were evident. Conscious and deliberate focusing on the language in CMC and using CMC opportunities for learning purposes may be viewed as evidence of autonomous behavior and may enhance such behavior on the part of foreign language learners. As stated by researchers, looking for and applying various, often original, sources of input for language practice and using any opportunity to improve and test one's language competence are important traits of autonomous learners. The following quotes seem to illustrate such an approach: "Generally, I take part in CM C for pleasure and social reasons, but I also signed up intentionally to some websites to improve my English;" "starting and maintaining such communication (CMC) is always pleasure-driven. I've never chatted with a foreigner solely to brush up on my language skills. Nevertheless, I've always considered CM C as a perfect occasion to do it. As a consequence, I'm always doing my level best to create exhaustive and clearly understandable messages;" "although in CMC 
personal reasons are always in the foreground for me, improvement of my English is an anticipated side-effect." Finally, one response made by a study participant clearly suggests that his/her CM C engagement was associated only with improving his/her language skills: "My participation in $\mathrm{CMC}$ is strongly connected with improving my English - I decided to take part in it in order to have more contact with English." This statement may be an indication of the respondent's autonomous approach toward learning English as it suggests an attempt to control and regulate learning processes; in other words, this and the previously quoted comments reveal a certain level of metacognitive behavior which underlies learner autonomy.

\section{Discussion and Implications}

On the basis of the study participants' responses presented in the previous section, it can be concluded that they largely claimed to be autonomous foreign language learners; most of them stated that they knew what helped them learn effectively, they looked for appropriate materials on their own, knew why they learned and what they wanted to achieve. Moreover, they admitted to look for opportunities to have contact with English and practice opportunities, which included seeking contacts with native speakers. The relatively high level of autonomy declared in the researched sample is hardly surprising, as the participants were adults and advanced learners, with considerable experience in learning a foreign language. On the other hand, it needs to be stressed that although the majority of the participants declared being independent learners aware of the learning processes and able to manage their own learning, some of them did not express a strong belief in their own autonomy as learners. Apparently, autonomy does not automatically come with age or learning experience.

Moreover, it needs to be stressed that part-time students' independence as learners and their autonomous involvement in learning appeared to be greater than those of regular students, at least according to their own estimations. Part-time students' motivation may have been better defined; they had to pay tuition, unlike regular students, and often needed a university diploma to improve their qualifications at a workplace. Moreover, since they attended classes only every second weekend, they may have been forced to devote more time to self-study and develop more autonomous learning behaviors. As a result, they claimed to have more clearly specified learning goals, better developed planning and self-evaluation abilities, and to be more conscious learning strategy users.

Similarly, although part-time students generally participated in all forms of $\mathrm{CMC}$ less frequently than did regular students, the study revealed that part- 
time students deliberately took more advantage of participating in CMC with the aim of practicing their English, apart from regular students' primary focus on the social and pastime dimension of interacting online. This was clearly highlighted in the comments that the regular students made about their involvement in CM C: Language development was considered as a by-product of engagement in meaningful interactions.

The accounts provided by the participants point to three basic features of autonomous learning, namely "learner involvement," "learner reflection" and "target language use" (Little 2007, p. 7), present in their CM C-related behavior. While engaging in different forms of $\mathrm{CMC}$, learners chose what to do, when, and to what extent, in this way learning to manage their contacts with the foreign language. While the participants admitted the main focus of their CMC was on conveying meaning, at the same time they also appreciated it as a source of valuable language input and an opportunity to practice communication skills. Moreover, they were apparently able to exercise control over their learning during $\mathrm{CMC}$ engagement, which is a vital condition of autonomous learning according to many researchers (e.g., Benson 2001, p. 141). Their use of CMC also enabled and encouraged them to manage and monitor their $L 2$ use and learning.

However, the study also revealed that the participants' awareness of what constitutes learner autonomy was rather limited and mainly associated with selfstudy or learning without help from a teacher. Although, in the light of the study findings, participating in CM C as part of out-of-class contact with English appeared to contribute to enhanced learner autonomy among the study participants, it may be concluded that this influence was only partly conceptualized by them.

Therefore, the main teaching implication emerging from the study is the constant need to guide the students toward understanding what autonomous learning really is and to try to develop fully reflective attitudes in them, thanks to which they are better prepared to evaluate themselves as autonomous learners. This can be done through a variety of instructional techniques, for example, through classroom-based discussions of the nature of autonomous learning, small-scale research-oriented team projects investigating their levels of autonomy or self-evaluation tasks fostered or followed by teacher-student dialogs. Offering guidance and suggestions concerning optimal learning tools and strategies is the primary role of a teacher in stimulating autonomous learning, both offline and online (e.g., Godwin-Jones, 2011). If learners can have sufficient hands-on experience with using various CM C forms within instructional settings, monitored by the tutor and provided with relevant feedback concerning its usefulness for effective learning, perhaps such strategies could be transferred to other, beyond-the-classroom, contexts. Even at an advanced level of language proficiency, some of the students still did not have 
well-defined learning objectives and felt they did not know how to learn. Awareness of how to make use of readily available CM C opportunities should be a part of learner development, so that they can be better appreciated by learners as a tool for fostering autonomy.

\section{Conclusions}

First of all, it needs to be stated that the study has a number of limitations. Some are connected with the fact that it relied exclusively on self-report data. As a consequence, the adequacy of the participants' accounts of what they do may be easily questioned. In addition, a limitation in the design of this study is the impossibility of examining what the students really did as part of their outof-class CM C engagement. M oreover, the generalizability of the study findings is limited, because, despite the relatively big sample size, the group was largely homogenous, as the participants came from the same cultural and educational background and studied at the same institution. Finally, the study participants studied at the same university at which the researcher was employed, and although only some of them (about 30) were taught by the researcher, being aware that she was involved in the organization of some courses might have influenced the way in which they responded to the questionnaires.

Finally, the study findings allow for the formulation of some conclusions concerning the potential of $\mathrm{CMC}$ environments to foster autonomous learning in advanced learners of English. The intensity of their CMC engagement in English can be interpreted as offering ample opportunities for authentic, meaningful interactions in English, which can contribute to the development of various components of the learners' communicative competence. By choosing to access Internet resources, both pedagogical and non-pedagogical in nature, in their own time and for their own purposes, learners demonstrate autonomous learning behavior and take responsibility over managing their learning through online interactions. It cannot be concluded, however, that all CMC situations lead to learning or to autonomy enhancement. Some CMC contacts are incidental or irrelevant enough not to have any impact on learning at all. Therefore, implicit or explicit guidance from teachers, through which learners will learn how to make their CM C contacts with English beneficial for their competence building, seems to be an appropriate idea. 
References

Abraham, L. B., \& Williams, L. (2011). Expanding discourse options through computer-mediated communication: Guiding learners toward autonomy. Foreign Language Annals, 44, 626-645.

Alm, A. (2006). CALL for autonomy, competence and relatedness: Motivating language learning environments in Web 2.0. JALT CALL Journal, 2, 29-38.

Arikan, A., \& Bakla, A. (2011). Learner autonomy online: Stories from a blogging experience. In D. Gardner (Ed.), Fostering autonomy in language learning (pp. 240-251). Gaziantep: Zirve University. Retrieved from http://ilac2010.zirve.edu.tr

Benson, P. (2001). Teaching and researching autonomy in language learning. Harlow: Pearson Education.

Benson, P. (2006). Autonomy in language teaching and learning. Language Teaching, 40, 21-40.

Benson, P. (2011a). What's new in autonomy? The Language Teacher, 35, 15-18. Benson, P. (2011b). Language learning and teaching beyond the classroom: An introduction to the field. In P. Benson \& H. Reinders (Eds.), Beyond the language classroom (pp. 7-16). Basingstoke: Palgrave Macmillan.

Blin, F. (2004). CALL and the development of learner autonomy: Towards an activity-theoretical perspective. ReCALL, 16, 377-395.

Collentine, K. (2011). Learner autonomy in a task-based 3D world and production. Language Learning \& Technology, 15, 50-67.

Darasawang, P., \& Reinders, H. (2010). Encouraging autonomy with an online language support system. CALL-EJ Online, 11. Retrieved from http://callej.org/journal/11-2/darasawang_reinders.html

Eneau, J., \& Develotte, C. (2012). Working together online: Analysis of learners' perceptions of their online learning experience. ReCALL, 24, 3-19.

Esch, E., \& Zächner, C. (2000). The contribution of Information and Communication Technology (ICT) on language learning environments or the mastery of the secret agent. ReCALL, 12, 5-18.

Gao, X., \& Zhang, L.J. (2011). Joining forces for synergy: Agency and metacognition as interrelated theoretical perspectives on learner autonomy. In G. Murray, X. Gao, \& T. Lamb (Eds.), Identity, motivation and autonomy in language learning (pp. 25-41). Bristol: Multilingual Matters.

Godwin-Jones, R. (2011). Emerging technologies. Autonomous language learning. Language Learning \& Technology, 15, 4-11.

Hafner, C., \& Miller, L. (2011). Fostering learner autonomy in English for Science: A collaborative digital video project in a technological learning environment. Language Learning \& Technology, 15, 68-86. 
Holec, H. (1981). Autonomy and foreign language learning. Oxford: Pergamon Press.

Hyland, F. (2004). Learning autonomously: Contextualising out-of-class English language learning. Language Awareness, 13, 180-202.

Jarvis, H. (2012). Computers and learner autonomy: Trends and issues. London: British Council.

Kaur, R., \& Sidhu, G. (2010). Learner autonomy via asynchronous online interactions: a Malaysian perspective. International J ournal of Education and Development Using Information and Communication Technology 6, 88-100.

Kaur, R., Singh, G., \& Embi, M. A. (2006). Learner autonomy through computer mediated communication. Jurnal Teknologi, 46, 99-112.

Lee, L. (2011). Blogging: Promoting learner autonomy and intercultural competence through study abroad. Language Learning \& Technology, 5, 87-109.

Little, D. (2000). Autonomy and autonomous learners. In M. Byram (Ed.), Routledge encyclopedia of language teaching and learning (pp. 69-72). New York: Routledge.

Little, D. (2007). Introduction: Reconstructing learner and teacher autonomy in language education. In A. Barfield \& S. H. Brown (Eds.), Reconstructing autonomy in language education: Inquiry and innovation (pp. 1-12). Basingstoke: Palgrave Macmillan.

Little, D. (2009). Language learner autonomy and the European Language Portfolio: Two L2 English examples. Language Teaching, 42, 222-233.

Luke, C. (2006). Fostering learner autonomy in a technology-enhanced, inquirybased foreign language classroom. Foreign Language Annals, 39, 71-86.

Luzón, M. J., \& Ruiz-M adrid, M. N. (2008). Learning to learn in a digital context: Language learning webtasks for an autonomising "wreading" competence. CORELL: Computer Resources for Language Learning, 2, 28-45.

M arkiewicz, W. (2008). E-learning jako narzędzie w rozwijaniu autonomii ucznia. In M. Pawlak (Ed.), Autonomia w nauce języka obcego - co osiqggnęliśmy i dokqd zmierzamy? (pp. 335-343). Poznań: Wydział Pedagogiczno-Artystyczny UAM w Poznaniu and Państwowa Wyższa Szkoła Zawodowa w Koninie.

Ng, S., Confessore, G., Yusoff, Z, Aziz, N., \& Lajiz, N. (2011). Learner autonomy and academic performance among undergraduate students. International J ournal of Social Sciences and Education, 1, 669-679.

Raby, F. (2007). A triangular approach to motivation in Computer Assisted Autonomous Language Learning (CAALL). ReCALL, 19, 181-201.

Reinders, H. (2011). Materials development for learning beyond the classroom. In P. Benson \& H. Reinders (Eds.), Beyond the language classroom (pp. 175-189). Basingstoke: Palgrave Macmillan.

Reinders, H., \& White, C. (2011). Learner autonomy and new learning environments. Language Learning \& Technology, 15, 1-3. 
Sadik, A. (2008). Digital storytelling: A meaningful technology-integrated approach for engaged student learning. Educational Technology Research and Development, 56, 487-506.

Shucart, S. A., M ishina, T., Takahashi, M., \& Enokizono, T. (2008). The CALL lab as a facilitator for autonomous learning. In F. Zhang \& B. Barber (Eds.), Handbook of research on computer-enhanced language acquisition and learning (pp. 483-495). Hershey, PA: IGI Global.

Ushioda, E. (2000). Tandem language learning via e-mail: From motivation to autonomy. ReCALL, 12, 121-128.

Ushioda, E. (2011a). M otivating learners to speak as themselves. In G. M urray, $X$. Gao, \& T. Lamb (Eds.), Identity, motivation and autonomy in language learning (pp. 11-24). Bristol: M ultilingual M atters.

Ushioda, E. (2011b). Why autonomy? Insights from motivation theory and research. Innovation in Language Learning and Teaching, 5, 221-232.

Villanueva, M. L, Ruiz-Madrid, M. N., \& Luzón, M. J. (2010). Learner autonomy in digital environments: Conceptual framework. In M. J. Luzón, M. N. RuizMadrid, \& M. L Villanueva (Eds.), Digital genres, new literacies, and autonomy in language learning (pp. 1-19). Newcastle-upon-Tyne: Cambridge Scholars.

Williams, M., \& Burden, R. L. (1997). Psychology for language teachers: A social constructivist approach. Cambridge: Cambridge University Press.

Wolski, B. (2008). Autonomiczna nauka w globalnej sieci. Czy studenci anglistyki efektywnie wykorzystuja internet do celów edukacyjnych? In M. Pawlak (Ed.), Autonomia w nauce języka obcego - co osiqgnęliśmy i dokqd zmierzamy? (pp. 219-232). Poznań: Wydział Pedagogiczno-Artystyczny UAM w Poznaniu and Państwowa Wyższa Szkoła Zawodowa w Koninie. 


\section{APPENDIX}

\section{The Data Elicitation Tools Used in the Study}

\section{Questionnaire 1}

Dear Students, I will be grateful for your filling in the questionnaire below. It serves research purposes and is anonymous. Thanks!

Age: years

Note: CM C is "communication between humans that is mediated by computer technology" (Levy and Stockwell 2006: 24)

1. How much time on average do you spend on computer-mediated communication (CMC)? hours a day on week days hours a day at weekends

2. Do you use the following forms of computer-mediated communication? If you do, in which language(s) do you communicate in these ways? Tick the ones that you use and the language of communication.

\begin{tabular}{|l|l|l|l|}
\hline \multicolumn{1}{|c|}{ CMCform } & In L1 & In English & $\begin{array}{c}\text { In another } \\
\text { language }\end{array}$ \\
\hline Email & & & \\
\hline Blogs & & & \\
\hline Discussion forums & & & \\
\hline Chats & & & \\
\hline Wikis & & & \\
\hline Instant messaging & & & \\
\hline Social networking sites & & & \\
\hline Virtual worlds & & & \\
\hline Skype & & & \\
\hline Other: & & & \\
\hline
\end{tabular}

3. How many times a week do you take part in CM C?
a. less than once a week
b. once a week
c. 2-3 times a week
d. more than 3 times a week
e. every day

4. How often do you use English while engaging in CM C? never - rarely - sometimes - often - very often 
5. Please mark the best-matching answers to the following statements according to the following key:

\section{1 - I strongly disagree, 2 - I disagree, 3 - I have no opinion, 4 - I agree, 5 - I strongly agree.}

1. I have well defined objectives in learning English

2. Ilearn English regularly, according to my own plan

3. I know how to evaluate my own progress in English

$\begin{array}{lllll}1 & 2 & 3 & 4 & 5 \\ 1 & 2 & 3 & 4 & 5 \\ 1 & 2 & 3 & 4 & 5 \\ 1 & 2 & 3 & 4 & 5 \\ 1 & 2 & 3 & 4 & 5 \\ 1 & 2 & 3 & 4 & 5 \\ 1 & 2 & 3 & 4 & 5 \\ 1 & 2 & 3 & 4 & 5 \\ 1 & 2 & 3 & 4 & 5 \\ 1 & 2 & 3 & 4 & 5 \\ 1 & 2 & 3 & 4 & 5 \\ 1 & 2 & 3 & 4 & 5 \\ 1 & 2 & 3 & 4 & 5 \\ 1 & 2 & 3 & 4 & 5 \\ 1 & 2 & 3 & 4 & 5 \\ 1 & 2 & 3 & 4 & 5\end{array}$

\section{Questionnaire 2}

Dear Students, please provide answers to the following two questions. Your responses should be spontaneous and honest; they don't have to be very long or particularly well organized, so don't worry that they will be evaluated in any way. I will be extremely grateful for your contribution.

1. Do you consider yourself an autonomous learner of English? Please justify your answer briefly.

2. If/When you take part in computer-mediated communication (through emails, instant messaging, blogging, etc.) in English, do you do it just for pleasure or social reasons, or do you ever intentionally plan to improve your English through CM C? 